\title{
Metaforologie en rasionaliteit
}

G M J van Wyk

Vanderbijlpark

\begin{abstract}
Metaphorology and rationality

In dialogue with the philosophers Foucault, Derrida, Habermas, Lyotard and Welsch, this study concentrates on broadening the context of research on metaphor from the philosophy of language to that of a contemporary critique of reason. The result of this approach is not only that metaphors are researched from within a new perspective, but also that the relation between metaphor and rationality is reviewed to the extent that it is demonstrated that rationality and even reality show a metaphorical structure at times.
\end{abstract}

\section{INLEIDING}

Die bedoeling van hierdie artikel is om aan te toon watter konsekwensies die eietydse redekritiek vir die ontwerp van 'n metaforologie inhou. Dit is nie hier moontlik om meer as net enkele verwysings na 'n paar denkers te maak nie. Die bedoeling is egter om aạn die hand van enkele voorbeelde aan te toon watter gevolge die eietydse redekritiek vir ' $n$ metaforologie en die daaraan onderliggende taalteorie inhou. Dit beteken egter nie dat die eietydse denkers wat hier bespreek word, willekeurig gekies is nie. Hulle word ter sprake gebring as gevolg van 'n onkonvensionele Kantresepsie wat by hulle almal te vinde is. Hierdie resepsie bring hulle daartoe om op ' $n$ idiosinkratiese wyse die (moderne) taalkritiese uitgangspunte van die bestaande metafoorteorieë op so 'n wyse aan 'n redekritiek te onderwerp. Sodoende het hulle daarin geslaag om redekritiek en taalkritiek op so 'n wyse op mekaar te betrek dat hulle kon aantoon dat die een nie sonder die ander onderneem kan word nie. Die benadering wat ekself hier volg en wat nie daarop afgestem is om ' $n$ teorie oor metafore te ontwerp nie, maar eerder begripshistories sowel metafore as die bestudering daarvan aan die orde te stel, noem ek metaforologie. Die gevolg van hierdie benadering is nie alleen dat daar uit ' $n$ nuwe perspektief na metafore gekyk kan word nie, maar ook dat die verhouding tussen metaforiek en rasionaliteit bedink word, en dat daar aangetoon word dat rasionaliteit en selfs die werklikheid by tye 'n metaforiese struktuur vertoon. 


\section{MICHEL FOUCAULT}

Met die denke van Kant word die Moderne Tyd betree. In hierdie tyd word die metafisiese beskouing dat daar ' $n$ korrespondensie tussen taal en wêreld bestaan, agtergelaat. En so gebeur dit dat die verteenwoordigingsfunksie van taal self problematies word: die taalvaardige subjek moet self tot objek gemaak word om klaarheid te probeer kry oor die prosedure waarvolgens taal verteenwoordigend vir wêreld gebruik kan word. In hierdie selfrefleksie word die subjek wat vir homself dinge voorstel, die laaste fondament van enige kennis gemaak. Die einde van die metafisika beteken ook die einde van 'n objektiewe en onproblematiese koördinering van dinge en voorstellings, terwyl die rol van die taal in so 'n proses onbedink bly (Habermas 1986:306). Die mens van die Moderne Tyd wat sy selfbewussyn ontdek het, ontvang saam met die ontdekking van sy selfbewussyn die bomenslike taak om die dinge in sy wêreld te orden op 'n tydstip wanneer hy juis ook vir die eerste keer radikaal van sowel sy outonomiteit as sy eindigheid bewus word.

Foucault is van mening dat die moderne kenvorm van die begin af deur die aporie gekenmerk word, naamlik dat die kennende subjek homself uit die gevangenisskap van die metafisika bevry het, om hom net weer te verslaaf met die wete dat die kenproses van die bewussyn oneindige krag vra, terwyl die mens net beperkte kragte het om aan te bied. Hierdie aporie is volgens Foucault die konstruksieprinsipe van Kant se kenteorie, omdat hy die beperkte eindige kenvermoë van die mens transformeer tot die transendentale voorwaardes van 'n oneindige voortstuwende kennis. Die grootste probleem met die bewussynsfilosofie van Kant is, volgens Foucault, die begripstrategiese dwang dat die kensubjek op 'n wyse verdubbel word sodat die verdubbelde subjekte in 'n ondraaglike kontradiksie tot mekaar staan (Foucault 1971:376). Hierdie onvermydelike, maar ondraaglike aspek van die bewussyn se selftematisering kom tot uitdrukking in 'n onbeheersde drang tot meer en meer kennis; 'n wil tot kennis, of 'n wil tot waarheid. Hierdie wil tot waarheid van die bewussynsfilosofie is vir Foucault die sleutel om die samehang tussen kennis en mag raak te sien. Hy gaan dan verder om die samehang tussen kennis en mag veralgemenend as 'n selfbemagtiging of as 'n magswil te verstaan. Uit hierdie hoek meen Foucault kan hy die heersende magspraktyke van ons dag verklaar (Foucault 1971:418). Foucault het op 'n vars wyse die kritiek van Nietzsche op Kant herhaal.

Tot op hierdie stadium is Foucault se denke vanuit 'n bewussynsfilosofiese invalshoek bespreek. Dit kan egter ook vanuit 'n ander hoek belig word, naamlik dié van die kenteorie as sodanig. Foucault meen dat daar twee breuke in die Westerse denkgeskiedenis aangetoon kan word, naamlik 'n breuk in die sewentiende eeu toe daar van 'n tradisionele tot 'n klassieke episteme oorgegaan is, en 'n breuk in die negentiende eeu 
toe daar van 'n klassieke tot 'n moderne episteme oorgegaan is (Foucault 1971:82). Hierdie twee breuke het die tipologie van kennis op so 'n wyse verander dat die nuwe op geen denkbare manier uit die oue afgelei kan word nie. Ons het dus hier met radikale diskontinuiteit te make. Welsch (1988:140) is van mening dat ons 'n tipiese kenmerk van die Franse gees in Foucault se denke teëkom, wanneer hy die diskontinuiteit van die episteme beklemtoon.

Welsch (1988:140) wys ook in hierdie verband op die verhouding wat daar tussen die denke van Foucault en die Franse Strukturalisme bestaan. Foucault se denke kan as Poststrukturalisme beskryf word en dit het later een van die voedingsbronne van die Postmoderne denke van ons dag geword. Sy denke toon aanvanklik 'n besliste ooreenkoms met dié van Lévi-Strauss, veral wat sy beskouing van die konstruksie van kennis betref. Lévi-Strauss was van mening dat die verskillende tipes en gebiede van kennis net op die oppervlakte ' $n$ differensiasie vertoon, maar dat dit in werklikheid net verskillende manifestasies van een en dieselfde episteme is. Daar bestaan in der waarheid 'n argeologiese monster van kennis wat onderliggend aan alle manifestasies van kennis is. $\mathrm{Hy}$ het hom daarom daarvoor beywer om na 'n universele en onveranderlike kode te soek aan die hand waarvan hy al die verskynsels van die kultuur en selfs die natuur tot in sy bio-chemiese bepaaldheid kan verklaar (Welsch 1988:141).

Aanvanklik wys Foucault op 'n sinchroniese homogeniteit wat daar tussen oënskynlik verskillende kenvorms bestaan, om later net weer op ' $n$ diachroniese opeenvolging van episteme-blokke te wys waartussen daar 'n onoorkombare heterogeniteit bestaan. Deur hierdie drastiese tese wys hy op die diskontinuïteit en heterogeniteit wat daar tussen verskillende episteme blokke bestaan. Tipologies gesproke bring hy deur sy denke die differensiasie-bewuste denke teenoor die dominante eenheidseffektiewe denke van sy tyd tot op die punt waar dit erkenning sou geniet. In die Strukturalisme het die mathesis-universalis-tradisie van die Nuwe Tyd gekulmineer; in die Poststrukturalisme van Foucault tree 'n teentradisie, naamlik 'n pluralistiese tradisie, na vore (Welsch 1988:141). Uit hierdie oogpunt beskou, het Foucault ook - ondanks sy kritiek op Kant - die denke van Kant op 'n sekere manier voortgesit. Hy het anders as die Laat Moderne Tyd se filosofie nie probeer om die Entzweiungen van die rede wat die gevolg van Kant se kenteoretiese denke was, ongedaan te maak of te oorwin nie, maar het in werklikheid daarop voortgebou om die differensiasiedenke uit te bou.

Die kenteoretiese denke van Foucault het implikasies vir die verstaan van die verhouding wat daar tussen taal en wêreld bestaan; en dan op so ' $n$ wyse dat dit ook van belang is vir die verstaan van metafore. Foucault is van mening dat daar in die tradisionele taalteorie ' $\mathrm{n}$ vorm van logofobie te bespeur is, wat daarin tot uitdrukking kom dat die woord tot die orde van 'n signifiant gereduseer word (Foucault 1971: 
82vv). Hy dui daarmee op die algemene opvatting dat dit uiteindelik nooit om die woorde self gaan nie, maar om dit wat deur die woorde beteken word. Deur hierdie reduksie word die woord van sy materiële en magtige werklikheid ontneem. Wanneer 'n woord alleen as 'n teken beskou word, word die oë gesluit vir wat die woord kan bewerk en uitrig. Op hierdie wyse word die politieke krag van woorde ook onderskat. Die beskrywing van woorde as waar of onwaar hou ook verband met hierdie opvatting van wat 'n woord is. 'n Waar woord is immers 'n woord wat die feitelike werklikheid op so 'n wyse beskryf dat dit so korrek moontlik weergegee word. Dikwels vergeet mense dat woorde die funksie het om iets te bewerkstellig of te verander. ' $n$ Woord is altyd ' $n$ instrument en dan 'n instrument waarmee die mens op die vlak van ' $n$ diskoers 'n magstryd betree. In 'n magstryd gebruik mens woorde om jou strategiese posisie te kan verdedig en bevorder. Die gebruik van woorde en 'n strategie van mag gaan altyd hand aan hand (Ijsseling 1979:92). Op hierdie punt kom Foucault se Nietzscheaanse bedoelinge ook duidelik na vore. Net soos Nietzsche is hy ook van mening dat dit by die gebruik van taal nie om die inhoud van woorde gaan nie, maar om die funksiewaarde van die vorm en dan op so 'n wyse dat die woord 'n magsinstrument is wat in diens van die wil tot mag staan.

Die denke van Foucault is ' $n$ aanduiding daarvan dat die kenteoretiese denktradisie wat oor Kant en Nietzsche loop, 'n geweldige relevansie vir 'n eietydse metaforologie het, vanweë die sterk nawerkingsgeskiedenis van hierdie tradisie in die hoofstroom van die filosofie van ons dag. Die sake wat deur hierdie tradisie op die tafel geplaas word, sal nouliks deur 'n eietydse metaforologie verbygegaan kan word.

\section{JACQUES DERRIDA}

Derrida vind aansluiting by Foucault deur die poststrukturalistiese Foucault teenoor die strukturalistiese Foucault af te speel en 'n primaat aan die differensiasie-denker toe te ken (Welsch 1988:143). Derrida vind 'n filosofiese strategie in sy aansluiting by Foucault, naamlik 'n strategie van fundamentele pluralisering. Vir Derrida is taal nie 'n eenheidsisteem nie, want dit praat baie tale tegelyk en dit bring baie tekste na vore. Derrida grens homself radikaal af van die soeke na eenheid wat die metafisiese tradisie so sterk bepaal het. Die elemente van pluraliteit moet, volgens Derrida, nie verstaan word as ideaaltipiese suiwer eenhede nie, maar as sineenhede wat op mekaar aangewese is, na mekaar verwys en oop is vir mekaar. Sin word alleen deur differensiasie aangebied. Dit beteken egter dat die differensiële oorspronklik is, in die sin dat dit nie moontlik is om iets te vind wat onderliggend daaraan is nie. Differensiasie beteken nie 'n atomistiese versplintering nie, maar dat sekere bane waarop daar beweeg word, verstrengel is en mekaar deurkruis, op so 'n wyse dat die bane met mekaar verbind word. 
Derrida het sy differensiasie-denke baie vrugbaar op die beskrywing van taal toegepas. Hy bedryf filosofie as 'n grammatologie wat daarop uit is om te verklaar waarom die wesenlike van taal vanuit die model van die skrif verstaan moet word, en nie vanuit die model van spreke nie. Hierdie onderneming van Derrida loop lynreg teen die Westerse metafisiese tradisie in. Die metafisika het nog altyd daarvan uitgegaan dat die logos as die rede in die gesproke woord gemanifesteer word. Derrida tipeer die metafisika as 'n logosentrisme wat op 'n fonosentrisme gebou is, en wat beveg moet word omdat dit nooit die primaat van die skrif teenoor die gesproke woord besef het nie (Derrida 1974:23). In sy grammatologie bedien Derrida homself van die metafoor van die boek van die natuur.

Die metafoor wat hier ter sprake kom, herinner daaraan dat die boek van die natuur alleen met groot moeite ontsyfer kan word, omdat dit in die moeilik ontsyferbare handskrif van God geskryf is (Derrida 1974:23). In hierdie verband siteer Derrida vir Jaspers: 'Die wêreld is die handskrif van 'n ander, nie volledig leesbare wêreld; alleen die eksistensie kan hierdie handskrif ontsyfer' (Derrida 1974:23). Deur hierdie sitaat wil Derrida daarop wys dat ons nie die oorspronklike teks het nie, dié is vir altyd verlore, slegs baie ander (sekondêre) tekste het oorgebly. Ons het trouens nog nooit die boek gehad wat in die handskrif van God geskryf is nie. Ons het nog net spore daarvan gevind en die spore self is maar baie vaag en onduidelik.

Derrida gebruik ook die metafoor van die boek om die projek van die moderne mee te beskryf (Derrida 1974:21). Die totale estetika en kritiek van die Moderne Tyd word daardeur bepaal dat die mens bewus geword het van die afwesigheid van goddelike tekens, maar tegelykertyd ook na 'n tuiste soek met behulp van hierdie tekens. Die Moderne Tyd was op soek na die spore van 'n boek wat nie meer soos die boek van die natuur of die Heilige Skrif, die totaal van 'n sinsamehang in die vooruitsig gestel het nie.

Die toepassing van die boekmetafoor binne die konteks van die moderne mens se soeke na sin, beklemtoon die katastrofiese oorleweringsgeskiedenis van tekste baie sterk. In so 'n katastrofiese oorleweringsamehang is die tekens van die geskrewe taal die enigste middel wat gebruik kan word om die korrupsie van 'n oorlewering teen te werk. Die geskrewe teks verseker die oorlewering van 'n woord, wat sou vervaag as die stem as medium ingespan sou word om dit oor te lewer. Skryftekens het 'n primaat bo taalklanke en ontsyfering gaan interpretasie vooraf. Trouens, tekste is gewoonlik so gefragmenteerd en beskadig dat mens nie so ver kan kom dat jy hulle kan interpreteer nie. Maar ook dan wanneer ons die spore van 'n ontwykende gees in 'n onverstaanbare teks vind, dan het ons nog die materie van die teken wat daarop dui dat die ontwykende gees wel dáár is. Verder is die skryfteken ook 'n waarborg daarvoor dat die teks altyd 
weer gelees kan word, selfs wanneer die konteks sou verander, of wanneer die skeppende gees lank reeds weg is. Elke skryfteken is in sy wese 'n testament wat vir die nageslag agtergelaat word (Derrida 1974:120).

Skrif herinner die leser met groot hardnekkigheid daaraan dat die skriftekens, ondanks die volledige afwesigheid van 'n subjek, of selfs wanneer die subjek al gesterf het, die ontsyfering van 'n teks moontlik maak en so die verstaanbaarheid daarvan ook in die vooruitsig stel, al kan dit nie gewaarborg word nie. Skrif is 'n testamentêre belofte dat verstaan ' $n$ moontlikheid is. Wanneer Derrida die model van die verwysingstruktuur van 'n skriftelike teks as uitgangspunt neem, bedryf hy 'n operasie wat van die subjek losgemaak is, sodat daar met subjeklose gebeure gewerk word. Skrif word dan verstaan as gewone oorspronklike tekens wat van al die pragmatiese samehange van kommunikasie losgemaak is (Derrida 1974:12).

Derrida se filosofie is ' $n$ poging om die transendentale subjek van Kant se filosofie met ' $n$ oergeskrif te vervang in 'n poging om die oorspronklik Aristoteliese opvatting dat taal as ' $n$ tekensisteem verstaan moet word, op ' $n$ ironiese wyse te rehabiliteer deur 'n primaat aan die retoriek teenoor die logika toe te ken. Deur hierdie benadering te volg, beweeg hy egter nog steeds binne die bane van die oorsprongsfilosofie. Nou is dit net nie meer die geskiedenis van die syn wat, soos in die metafisika, die eerste en die laaste is nie, maar die 'labirintiese spieëleffek' (Habermas 1986:211) van ouer tekste, wat op hulle beurt na nog ouer tekste verwys en so die hoop wek dat 'n oerskrif gevind kan word. Wat egter belangrik is, is dat Derrida meen dat taal as die gebruik van skriftekens ten diepste ' $n$ tekenkarakter en nie 'n gelykeniskarakter vertoon nie.

Derrida se filosofie bly baie na aan die Joodse mistiek (Habermas 1986:214). Derrida wil nie met sy filosofie probeer om op 'n neopagane wyse na 'n oorsprong te soek wat verder in die verlede terug lê as die begin van die monoteïsme nie. Hy vind aansluiting by die Kabbalistiese tradisie wat met die idee van 'n mondelinge Tora wil aantoon dat die waarheid nie fikseerbaar is nie. Die mondelinge Tora gaan op woorde van mense terug en kan daarom nie aan die Bybel as die presumptiewe woord van God gelyk gestel word nie. Later kom daar nog 'n radikaler standpunt binne die Kabbalatradisie na vore: die skriftelike Tora word ook as 'n problematiese vertaling van God se woord in die taal van mense gesien; dit is bloot 'n volgende aanvegbare interpretasie. Alles - die mondelinge tradisie en die Heilige Skrif - is niks anders as mondelinge Tora nie. Derrida se grammatologiese idee van 'n oergeskrif wat net meer en meer interpretasies tot gevolg het, gaan op hierdie mities-Kabbalistiese tradisie terug. Hy keer met sy filosofie na die historiese punt toe terug waar die mistiek in die Verligting omgeslaan het (Habermas 1986:218).

Derrida se filosofie kan ook as ' $n$ kritiek van die rede verstaan word. Hy gaan van die Kantiaanse insig uit dat ' $n$ kritiek van die rede altyd ook op die rede self gerig moet wees, maar radikaliseer die posisie van Kant deur te stel dat 'n totaliserende selfkritiek 
van die rede 'n teenspraak is, omdat die subjekgesentreerde rede op sy eie middele aangewese bly om ' $n$ totale selfkritiek deur te voer. Derrida probeer om met sy filosofie uit hierdie paradoks te breek. Hy doen dit deur die soewereiniteit van die retoriek teenoor die logika te proklameer en op hierdie wyse van die dwang tot 'n totaliserende redekritiek te ontsnap. Derrida redeneer nie alleen met Foucault teen Foucault nie, maar ook met Aristoteles teen Aristoteles. Hy verdedig die beskouing dat taal ten diepste uit die gebruik van tekens bestaan, maar terselfdertyd gee hy die primaat prys wat die logika volgens Aristoteles teenoor die retoriek het.

Derrida kritiseer die filosofie van die subjek. Hy verbind egter sy kritiek op die filosofie van die subjek met 'n radikale redekritiek, sodat die rede slegs as 'n objektiewe genitief ter sprake kan kom, byvoorbeeld in dié sin dat daar net nog sprake van die rede kan wees in ' $n$ uitdrukking soos 'die rede op sigself is funksieloos'. Dit hou in dat enige vorm van teoretiese verantwoordelikheid en metodiese denke deur hom agtergelaat word. 'n Rasionalisties gekleurde filosofie is volgens hom nie moontlik nie. Habermas se filosofie is 'n sterk reaksie op die filosofie van Derrida wat logosentrisme-krities en poststrukturalisties teen die hele Westerse denktradisie, wat uit die metafisika na vore gekom het, gerig is. Habermas is van oortuiging dat Derrida verkeerd is wanneer hy die standpunt verdedig dat die Westerse tradisie te redelik probeer wees (Van Wyk 1989:9). Volgens Habermas (1985:136) is die Westerse denke nie te redelik nie, maar nie redelik genoeg nie. Vervolgens stảan ons by hierdie kritiek van Habermas - wat ook 'n kritiek van die rede is - stil.

\section{JÜRGEN HABERMAS}

Habermas vind in sy redekritiek aansluiting by die filosofieë van Foucault en Derrida. Hy meen hierdie filosofieë bied 'n aanknopingspunt in die feit dat hulle die tweehonderd jaar oue bewussynsfilosofiese paradigma - wat met die sleutelbegrippe 'subjek' en 'bewussyn' werk - probeer oorwin het. Hy meen verder dat hierdie prysgawe van die bewussynsfilosofiese paradigma die grootste filosofiese prestasie van ons tyd is en dat dit met Kant se ontwerp van 'n transendentale filosofie vergelyk kan word (Habermas 1985:134).

In 1981 het Habermas se Theorie des kommunikativen Handelns in twee bande verskyn. Met hierdie werk wil hy die kritiese maatstawwe vir 'n samelewingsteorie beskryf. Hy beklemtoon dat hierdie werk nie 'n metateorie of die voortsetting van die kenteorie met ander middele is nie. Hy gee die primaat wat die kenteorie in die filosofie geniet het, prys. Dit beteken dat hy die vooronderstellings van skikkingsgeoriënteerde handeling onafhanklik van die transendentale vooronderstellings van kennis behandel (Habermas 1981:7; Habermas 1982:10). Hierdie wending van 'n 
kenteorie na 'n kommunikasieteorie plaas Habermas in die posisie om substansiële antwoorde te gee op die vrae waarvan die veronderstellings slegs binne die raamwerk van die vorige paradigma blootgelê kon word, of wat net verduidelik kon word vanuit 'n metateoretiese posisie. Omdat hy nie meer met die transendentale vooronderstellings van kennis werk nie, is hy ook bevry van die dwang wat die transendentale filosofie andersins op hom sou lê, naamlik om 'n filosofie van die subjek te bedryf. Hy ontwikkel nou die identiteit van handelingsisteme uit die interaktiewe verhouding wat daar tussen twee subjekte wat mekaar onderling erken, bestaan. Hy hoef nie meer, soos die transendentale filosofie, die eienskappe van die transendentale Ek op die kollektiewe vlak te projekteer nie (Habermas 1982:402). Habermas verruil dus die kenteorie vir die kommunikasieteorie as die paradigma van sy filosofie (Habermas 1986:345). Die waarde van hierdie paradigmawisseling lê daarin dat hy nie meer probeer om sosiale handeling in die lig van die subjek-objek verhouding te definieer nie (Habermas 1986:375). Anders gesê, gaan hy nie meer van die objektiewe houding van 'n waarnemer van sake uit nie, maar van die intersubjektiewe houding van 'n deelnemer aan diskoerse. Hy gebruik deurgaans die intersubjektiewe verhouding as uitgangspunt om sosiale handeling te verstaan (Benhabib 1986:xi).

Hierdie invalshoek stel Habermas in staat om Nietzsche se Kantkritiek op 'n ander vlak te herhaal. Habermas wil soos Nietzsche die transendentale bewussynskritiek van Kant op die vlak van die taallogika herhaal. Anders as Nietzsche, wat tot die gevolgtrekking gekom het dat alle aansprake van die rede prysgegee moet word in die lig van die menslike wil se heerskappy oor die rede, met die gevolglike opheffing van die soeke na die waarheid in die vraag na die nodigheid om sekere waarhede veronderstel, hou Habermas vas aan die sterk aansprake van die rede teenoor die wil van die mens. Hy meen dat die Westerse filosofie nie te redelik is, soos wat Derrida beweer nie, maar dat dit eerder mank gaan aan redelikheid. Derrida het volgens hom die totaliserende selfkritiek van die rede as paradoksaal verstaan, omdat hy nie in ag geneem het dat 'n totale selfkritiek van die rede nie beteken dat alles gelyk gekritiseer moet word nie, maar dat dit slegs beteken dat jy die vooronderstellings waarvan die rede uitgaan, ook aan kritiek moet onderwerp. Habermas meen teenoor die Nietzscheaanse filosofie dat wanneer die sleutelposisie wat die bewussyn in die paradigma van die filosofie ingeneem het deur die vraag na die moontlikhede om ander subjekte te kan verstaan, oorgeneem word, kan 'n analise van ons kommunikatiewe praktyk van elke dag die ingeboude potensiaal van die rede weer onverkort aan die lig bring (Habermas 1985:137).

Watter rede(s) kan Habermas aanvoer om sy verandering van filosofiese paradigma te verdedig? Dit is so dat Habermas binne die basiese lyne van Kant se filosofie beweeg, in die sin dat hy ook na 'n samebindende rasionele krag vra, sonder om die redelikheid tot een noemer te reduseer, maar hoe kan hy hierdie onderneming regverdig 
in die lig van die aangekondigde paradigmawisseling? Habermas het vrae in hierdie verband die nek in geslaan deur na die terminus a quo van die kultuur te vra. Die resultate van Habermas se studies in hierdie verband bied die nodige gronde vir sy paradigmawisseling aan.

Habermas weier om die vraag na die terminus a quo van die kultuur, en ander soortgelyke substansiële vrae wat in die geskiedenis van die Westerse filosofie na vore geroep is, anders as letterlik te verstaan. Dit impliseer dat hy, sterker as Foucault en Derrida, weer aansluiting soek by die Westerse filosofiese tradisie. Daarom is hy ook nie te vinde vir die formulering van substituutvrae, soos wat Nietzsche en sy volgelinge dit gedoen het nie. Habermas (1981:7) is van mening dat die beantwoording van substansiële vrae en die formulering van grondbegrippe 'n onlosmaaklike eenheid vorm. Die vraag wat hier op die tafel geplaas word, moet gevolglik nie omseil word nie, maar beantwoord word deur die nodige begrippe te skep wat kan help met die beantwoording van die vraag. Die begrip wat Habermas gebruik om die vraag na die terminus a quo van die kultuur bevredigend te kan antwoord, is die begrip 'kommunikatiewe handeling'.

Wanneer taal as ' $n$ vorm van kommunikatiewe handeling verstaan word, is dit volgens Habermas nie moeilik om raak te sien dat die terminus a quo van die kultuur in die ontwikkeling van simbolies bemiddelde handeling na taal te vinde is nie (Habermas 1981 Bd. 2:118). Habermas reken dat hy ook 'n kultuurteoretiese hipotese kan opstel om hierdie insig te onderskryf. Sy hipotese is dat daar 'n samehang bestaan tussen handeling wat deur norme bepaal word en die grammatikale rede. Hierdie samehang bestaan nie toevallig nie, maar dit kan afgelees word uit die rasionele struktuur van die ver-taal-ing van die sakrale. Die sakrale rites wat as handelingsbegronding gedien het en deur die outoriteit van die Heilige ondersteun is, het deur 'n proses van ver-taal-ing plek gemaak vir die begronding van handeling deur 'n proses wat konsensus onder mense bewerk het. So word kommunikatiewe handeling uit 'n sakraal ondersteunde normatiewe konteks gedistilleer. Deurdat die normatiewe konsensus wat ritueel ondersteun word, ver-taal word, word die kommunikatiewe handeling met sy rasionele potensiaal blootgelê. Habermas verstaan taalhandelinge wat op die bereiking van konsensus gerig is, nie alleen as rasioneel gemotiveerde dade wat die mens help om sin te vind in ' $n$ wêreld waar instrumentele handeling domineer nie, maar ook as 'n manier om voorlopige antwoorde op substansiële vrae te gee. In hierdie sin het kommunikatiewe handeling grootliks die rol oorgeneem wat absolute metafore in die verlede vervul het. Kommunikatiewe handeling staan egter nie vyandig teenoor die gebruik van metafore nie; metafore kan vrugbaar aangewend word om konsensus te bewerk. 
Habermas reken dat hy met die teorie van die kommunikatiewe handeling oortuigend aangetoon het dat die tese dat die Postmoderne Tyd aangebreek het, ongegrond is. Hy meen verder dat die redekritiek van die postmodernisme in 'n teenspraak verval het. Die postmodernisme wend 'n poging aan om 'n argumentatiewe likwidasie van die rede deur te voer, maar land dan met hierdie strategie in die dilemma dat daar van die argumentatiewe gebruik van die rede afskeid geneem word, sonder dat daar op 'n oortuigende wyse 'n substituut daarvoor aangewys kon word.

Welsch (1988:164) is van mening dat Habermas se argument self ook bedenklik is, omdat hy in sy konfrontasie met die postmodernisme een filosoof verbygegaan het wat nie deur sy kritiek getref word nie. Hierdie filosoof is Lyotard. Sy filosofie is nie vyandig teenoor die rede nie, dit is nie irrasioneel nie en dit is ook nie 'n filosofie van die subjek, of 'n oorsprongsfilosofie nie. Lyotard verstaan die Postmoderne as die radikaal Moderne en daarom is hy van mening dat dit ook nie teenoor die Moderne afgespeel kan word nie. Welsch stel verder dat dit moeilik is om Habermas se eie filosofie anders te verstaan as 'n Postmoderne filosofie in dieselfde styl as die styl van Lyotard. Hoe kan sy kritiek op die subjekgesentreerde rede van die Moderne en sy oproep tot 'n paradigmawisseling na die paradigma van die kommunikatiewe rede anders as ' $n$ vorm van Postmoderne filosofie verstaan word wat bloot dit vermy om self die naam 'postmodern' te gebruik?

\section{JEAN-FRANCOIS LYOTARD}

Die Moderne Tyd is gekenmerk deur die feit dat belangrike sake gelegitimeer is aan die hand van metavertellings, of anders gestel, deur betoë in narratiewe vorm oor die groei van kennis en die uitbouing van kultuur. Die grondstelling van Lyotard se programskrif La Condition postmoderne: Rapport sur le savoir (hier aangehaal as The postmodern condition: A report on knowledge 1984:15) is dat die legitimerende krag van metavertellings opgehef is; dat ons nie meer geloof in sulke vertellings het nie. Die drie groot metavertellings van die Moderne Tyd, naamlik die verligtingsverhaal van die emansipasie van die mensheid, die idealistiese verhaal van die teleologie van die gees en die historiese verhaal van die hermeneutiek van sin het nie meer enige universele nawerking in die hede nie. Daarmee sê Lyotard nie dat hierdie verhale nie meer in die huidige situasie te vinde is of vir baie mense as uitgangspunt in hulle denke dien nie. Hy wil net die insig uitlig dat hierdie verhale nie meer algemene geldigheid of legitimerende krag het nie. Dit beteken dat die inhoud van hierdie verhale nie antikwaries geraak het nie, maar dat die vorm waarin hulle gegiet is, uitgedien geraak het. Lyotard meen dat daar twee redes aangevoer kan word vir die opheffing van die legitimerende 
krag van die metavertellings: die eerste is dat geen mens in die posisie is om 'n uitspraak met universele geldigheid te maak nie; en die tweede is dat die mens die bedrog van die totaliteit deurskou en geleer het om die veelheid raak te sien en te herken.

Lyotard span 'n spesifieke metode in om te filosofeer, naamlik om op die gebruik van taal te fokus. Net soos wat die Moderne Tyd gekenmerk is deur die aanwending van groot metavertellings, so word die Postmoderne Tyd gekenmerk as die tyd waarin kennis verteenwoordig word deur 'n spel met taal waarin jy, deur te praat, aan die spel kan deelneem met dic bedoeling om nuwe en altyd veranderende sosiale bindinge te vorm. Deur op die groot verskeidenheid van taalspele te fokus, toon hy aan dat die Postmoderne Tyd van die ganse of die geheel afskeid geneem het en na 'n pluraliteit oorgegaan het. Die Fostmoderne Tyd wil nie die Moderne Tyd bedreig nie, maar wil die demokratiese tradisie van dié tyd opneem en dit uitbou tot 'n radikaal demokratiese visie (Welsch 1988:182). In die Postmoderne Tyd word pluraliteit grondig herken en toegelaat om te bestaan. Alleen onder hierdie omstandighede word demokrasie sinvol. Die postmoderne gees is in sy wese 'n demokratiese gees. Anders as Habermas meen Lyotard nie dat die bereiking van konsensus die hoogste ideaal is om na te streef nie, maar wel die herkenning van pluraliteit. Alleen op so 'n wyse meen hy kan daar vir die demokrasie ruimte gemaak word.

In 'n later werk Le Différend (hier aangehaal as Der Widerstreit 1987:11-12) ontvou Lyotard weer die tema van pluraliteit op 'n taalfilosofiese basis. Hy oriënteer hom egter nie meer aan die analisering van taalspele nie, maar aan diskoerssoorte (genres de discours).

Lyotard meen dit is onmoontlik om te praat sonder om 'n onreg te begaan. Wanneer mens taal gebruik, word jy gedwing om een diskoerssoort te kies, want jy moet praat, maar so 'n keuse geskied onvermydelik ook ten koste van ander moontlike diskoerssoorte. Daar is ook geen definitiewe kriteria wat vir die keuse van 'n diskoerssoort aangelê kan word nie. Die rede hiervoor is dat die verskillende diskoerssoorte nie bloot verskillend verskyn nie, maar dat hulle werklik heterogeen is. Hulle is nie bloot verskillende gestaltes van ' $n$ homogene saak nie. Dit beteken dat daar geen metareëls kan bestaan aan die hand waarvan konflikte in verskillende diskoerssoorte besleg kan word nie. In taal bestaan geen geregtigheid nie, want sekere diskursiewe moontlikhede word nooit geaktualiseer nie, terwyl dit ' $n$ reg het om geaktualiseer te word. Die ontbreking van ' $n$ metareël vir die beslegting van diskursiewe konflikte maak die hart van Lyotard se postmodernisme uit (Welsch 1988:232)

Wanneer Lyotard op die struktuur van taal fokus, kom hy tot die gevolgtrekking dat daar nie iets soos dié taal of taal in die algemeen is nie. Tussen verskillende diskoerssoorte bestaan daar ' $n$ fundamentele onderskeid, sodat daar nie oorkoepelende 
taalreëls kan bestaan nie. Binne 'n diskoers is 'n oorgang van een reëlsisteem na 'n volgende wel moontlik, en so 'n oorgang is gewoonlik ook nie problematies nie, maar die oorgang van een vorm van diskoers na ' $n$ volgende is so problematies dat dit nie deurgevoer kan word nie. Intrageneriese konflikte is oplosbaar, maar intergeneriese teensprake is nie oplosbaar nie (Welsch 1988:233). Daar bestaan nie 'n gemeenskaplike idioom waarmee sulke teensprake uit die weg geruim kan word nie.

Lyotard se poging om uit hierdie dilemma te kom, het meer fasette. Hy bedien hom van metaforiese taal om die probleem wat hier op die tafel is, te hanteer. Soos Kant, maak Lyotard met vrug van die geregshofmetafoor gebruik. Die grondprobleem van die juridiese prosedure is dat die regter self nie bo die situasie kan staan nie, maar self ook noodwendig partydig is. Dit beteken nou nie dat die regter noodwendig kant kies in 'n saak nie, maar dat die regsordening as sodanig ook 'n party vorm in die regsprosedure. Met hierdie wete kan die stryd om onreg te bekamp nou op twee vlakke voorgesit word. Teoreties kan mens die onregsmasjinerie probeer aftakel, maar dan stuit jy voor die probleem dat daar nie ' $n$ omvattende metataal bestaan waarmee hierdie aftakelingsproses kan geskied nie. Prakties kan mens probeer om deur die heersende diskoers die party wat tot swye gedwing is, se standpunt weer geartikuleer te kry. Dit beteken dat mens ook die begrip van geregtigheid sal moet transformeer: geregtigheid kan nie meer in die regter self gesetel wees nie, maar alleen in die taal. Dit beteken verder dat ' $n$ teenspraak as sodanig erken sal word en nie tot ' $n$ blote (woorde-) stryd afgemaak sal word nie. Dit is dan ook die opgawe van die filosofie om die veelheid en heterogeniteit van taal in die wydste moontlike sin aan die lig te bring. So kan filosofĩe as Moralia linguistica verstaan word (Welsch 1988:239). Die aktualisering van die idee van humaniteit bly die ideaal en die opdrag van die projek van die postmoderne.

Lyotard gee die aanspraak op universele geregtigheid, en daarmee saam die idee van dié geregtigheid, prys. Dat geregtigheid geregtigheid vir almal moet wees, is onskeibaar van enige idee van geregtigheid. Aan hierdie idee van geregtigheid hou hy egter vas. Sy hele filosofie is daarop afgestem om die geregtigheidsfeer uit te brei. Elke verborge vorm van sistematiese onreg moet oopgevlek en beveg word. Geregtigheid is as 'n positiewe realiteit onmoontlik, maar as ' $n$ idee bly dit verpligtend. Dit beteken dat die heterogene altyd moet domineer. Onreg moet altyd oopgevlek word, want dit is 'n groter moontlikheid as om reg te doen. Om die goeie te doen, is nie vir ons bestem nie, maar dit is wel vir ons bestem om teen onreg en kwaad te veg. Dít is tans die vorm van geregtigheidsarbeid waarmee ons moet besig wees (Welsch 1988:240).

Welsch (1988:259) wys daarop dat Lyotard hom in die laaste plek ook moes bemoei met die vraag na die oòrgange of die moontlikheid van oorgange tussen verskillende diskoerssoorte. In hierdie verband het hy twee soorte oorgange geïdentifiseer, naamlik intrageneriese- en intergeneriese oorgange. Welsch is van mening dat hierdie 
twee soorte oorgange in der waarheid nader aan mekaar lê as wat Lyotard geglo het. Die intrageneriese- en intergeneriese oorgange is nóg so eenvoudig reëlgebonde, nóg so eenvoudig reëlloos, as wat Lyotard van mening was en die twee oorgange is ook gelyker aan mekaar as wat die polêre beskrywing daarvan te kenne gee. In beide gevalle kom dit jenseits die reëlgebondenheid en diesseits die reëlloosheid daarop neer om 'n voortsettingsmoontlikheid te vind wat sinvol is binne die spesifieke situasie (Welsch 1988:260). In albei gevalle gaan dit oor die soeke na 'n besondere vorm van redelikheid. Welsch is van mening dat hy 'n teorie van só 'n redelikheid soos dié waarna Lyotard op soek is, kan ontwikkel. Hy noem die teorie die teorie van die transversale rede. Ten slotte staan ons by dié teorie stil.

\section{WOLFGANG WELSCH}

Welsch (1988:295) meen dat die eenheid van die rede, in die lig van die veelheid van sy vorms, daaruit moet bestaan dat daar oorgange tussen die verskillende vorms van redelikheid moontlik is. Dit beteken dat die rede meer as net 'n formele algemene begrip moet wees. Die rede is dit wat in die hede - in die lig van die heersende pluraliteit - oor die vermoë beskik om verbindings en oorgange tussen verskillende redelikheidsvorme te bewerkstellig. Dit beteken nie dat die rede die pluraliteit oorwin nie, dit oorkom net die aporieë wat deur die pluraliteit ontstaan het. So bring dit die pluraliteit as 'n vorm van redelikheid na vore.

'Transversale rede' beteken nie 'n nuwe en daarom besondere soort redelikheid nie, maar dit karakteriseer 'n bepaalde nuut geaksentueerde verstaan van redelikheid (Welsch 1988:296). Hierdie nuwe verstaan van redelikheid hou veral in dat rasionaliteit as 'n immanente korrelasie en 'n vervlegting van rasionaliteitstipes verstaan word. Verskillende rasionaliteite kan nie deur sektoriale definisies tot monadiese aangeleenthede verklaar word nie. Onwillekeurig sal uitsprake oor een tipe rasionaliteit ook ander tipes van rasionaliteit raak. Rasionaliteit kan daarom nie alleen binnesektoriaal gedefinieer word nie, want dit moet ook transsektoriaal gekonstelleer word. Dit beteken egter nie dat elke vorm van rasionaliteit op elke volgende vorm van rasionaliteit betrekking het nie. Dit het net op enkele aangrensende sektore betrekking. Dit beteken dat ' $n$ bepaalde wetenskaplike paradigma nie meer universele geldigheid kan hê nie, maar nog net geldigheid vir 'n sekere reeks van rasionaliteitsvorms wat op 'n bepaalde wyse korrespondensie met mekaar vertoon. Die suiwer sektoriale rasionaliteitsopvatting is ontoereikend, want intersektoriale verbande, transmediale ooreenkomste en transsektoriale analogië moet ook in ag geneem word. Daar is nie alleen verskillende vorms van rasionaliteit nie, maar die oorgange tussen hierdie verskillende vorms is ook in ' $n$ hoë mate gedifferensieerd. 
Die vervlegting wat daar tussen die verskillende tipes van rasionaliteit bestaan, open die moontlikheid dat oorgange tussen die verskillende rasionaliteite moontlik is. Die rede hou hom besig met die dimensie waarbinne dié oorgange plaasvind. Omdat die rede se dimensie dié van oorgange is, moet dit van alle substansiële, prinsipiële en universele opvattings gereinig word. Dit beteken dat die rede net op drie vlakke werksaam kan wees: as 'n refleksie oor die verskillende vorms van rasionaliteit en die oorgange daartussen, om 'n praksis vir hierdie oorgange te bewerk en om as medium te dien vir die hantering van konflik tussen heterogene aansprake. Dit beteken dat die rede 'n meta-rasionele vermoë is, maar dan veral as 'n inter-rasionele vermoë. Die domein van die rede bly dié van oorgange. Dit vereis van die rede om met verskille en identiteite te kan omgaan, sonder om bevooroordeeld te wees. Die rede is niks meer as die vorm van ' $n$ inter-rasionele proses nie.

Wat Welsch 'transversale rede' noem, is onmiskenbaar met dit wat tradisioneel as 'oordeelskrag' getipeer is, identifiseerbaar. Dit is veral die geval wanneer 'oordeelskrag' 'n reflekterende vorm aanneem, soos wat dit in die filosofie van Kant die geval is. Kant was van mening dat die morele rede onmagtig is, omdat dit nie oor die middele beskik om dit te laat realiseer wat dit verkondig nie. Hierdie besef het Kant gedwing om 'n estetiese wending aan sy filosofie te gee (Marquard 1989). Die skryf van sy derde kritiek kan hieruit verstaan word. Die oplossing wat Kant in § 59 van die Kritik der Urteilskraft aan die hand doen om aan die aporie van die praktiese rede te ontkom, is dat die goeie syn nie gerealiseer moet word nie, maar gesimboliseer moet word. Hierdie oplossing van Kant is 'n goeie demonstrasie van presies dit waarvoor Welsch die transversale rede wil inspan.

Welsch soek 'n oplossing vir die probleem van die oorgange tussen verskillende vorms van rasionaliteit op dieselfde wyse as wat Kant dit gedoen het. Hiermee grens hy hom sterk af teen die alternatiewe standpunt van Hegel. 'Hegel', sê hy, 'meen met "oorgange" iets gans anders as wat hier [by Welsch self] die geval is. Hegel se oorgange is teleologies, dit beteken die opheffing van die voorafgaande in die voortgaande gang van die ontwikkeling van die gees' (kyk ook Bloch 1972:38). Hierteenoor is die konsep van die transversale rede nóg 'n teleologiese prinsipe, nóg 'n opheffing vari die bestaande, nóg 'n totalisering (Welsch 1988:309), ' maar wel 'n interrasionele vermoë.

Welsch se identifisering van rede met oordeelskrag dui op 'n besliste grensbewussyn. Hy sê caat die definisie van die wysheidstradisie dat die wete van 'n nie-wete altyd tot die wete behoort, belangrik bly (Welsch 1988:326). In die filosofie kom dit altyd op ' $n$ bewustheid van grense en op 'n besorgdheid oor die totaliteit neer. Dit beteken dat filosofie nie net wetenskap kan wees nie. Dit moet meer as wetenskap wees. Dit moet ook wysheid wees. Filosofie is egter nie net wysheid nie. Dit staan altyd in 'n balans tot sowel wetenskap as wysheid, maar sonder die wysheidsmoment verval dit. 


\section{SLOT}

Sonder dat Welsch dit in soveel woorde sê, deel hy Martin (1965:332) se mening dat

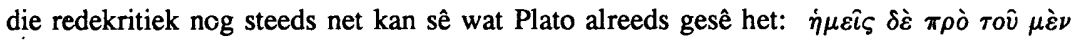
$\hat{\dot{\varphi}} \hat{o} \mu \varepsilon \theta \alpha, \nu \hat{\nu} \nu \delta^{\prime} \dot{\eta} \pi o \rho \grave{\eta} \kappa \alpha \mu \varepsilon \nu$ (Vroeër het ons geglo dat ons weet, maar nou is ons radeloos).

In die eietydse redekritiek is die historiese bewussyn van die rede tot ' $n$ universele grensbewussyn verwerk. 'n Teorie van metafore wat probeer om 'n botydelike konstante by metafore te probeer aandui, is by voorbaat tot mislukking gedoem; terwyl 'n begripshistoriese benadering wat eerder op differensiasie en pluraliteit konsentreer, weer belowend lyk as 'n benaderingswyse vir die bestudering van metafore. Dit beteken dat ' $n$ narratologiese aanslag wat pluraliteit baie gerieflik kan akkommodeer, eerder as ' $n$ teoretiese aanslag wat meer op eenduidigheid ingestel is, gebruik kan word vir die bestudering van metafore.

'n Verdere vraag het ook aan die lig gekom, naamlik of daar op 'n redelike wyse met die rede omgegaan moet word, en indien wel, hoe dit dan gedoen kan word. Uit die eietydse redekritiek blyk dit dat daar wel op 'n redelike wyse met die rede omgegaan moet word en dat die manier van omgang onder andere die moontlike oorgange of verbindings van die verskillende vorms van rasionaliteit moet bedink. Met die beantwoording van die vraag na die oorgange tussen die verskillende rasionaliteitsvorms het die filosofie voor die werklikheid van die onbegryplike gestuit. Die grootste winspunt van die eietydse redekritiek is ' $n$ grondige besef van die grense van die rede.

\section{Literatuurverwysings}

Benhabib, C 1986. Critique, norm and utopia: A study of the foundations of critical theory. New York: Columbia.

Bloch, E 1972. Subjekt-Objekt: Erläuterungen zu Hegel. Frankfurt am Main: Suhrkamp.

Derrida, J 1974. Grammatologie. Frankfurt am Main: Suhrkamp.

Foucault, M 1971. Die Ordnung der Dinge: Eine Archäologie der Humanwissenschaften. Frankfurt am Main: Suhrkamp.

Habermas, J 1981a. Die Moderne - ein unvollendetes Projek, in Kleine Politische Schriften, I-IV. Frankfurt am Main: Suhrkamp.

— 1981b. Theorie des kommunikativen Handelns. 2Bde. Frankfurt am Main: Suhrkamp.

- 1982. Zur Logik der Sozialwissenschaften. Frankfurt am Main: Suhrkamp. 1984a. Gershom Scholem - Die verkleidete Tora, in Philosophisch-politische Profile. Frankfurt am Main: Suhrkamp. 
Habermas, J 1984b. Wozu noch Philosophie?, in Philosophisch-politische Profile. Frank-furt am Main: Suhrkamp.

1984c. Walter Benjamin: Bewußtmachende oder rettende Kritik, in Philosophisch-politische Profile. Frankfurt am Main: Suhrkamp

1985. Die Neue Unübersichtlichkeit: Kleine Politische Schriften, V. Frankfurt am Main: Suhrkamp.

— 1986. Der philosophische Diskurs der Moderne. Frankfurt am Main: Suhrkamp.

Ijsseling S \& et al. 1979. Denken in Parijs. Brussel: Samsom Uitgeverij.

Lyotard, J-F 1984. The postmodern condition: A report on knowledge. Manchester: Manchester University Press.

1987. Der Widerstreit. Frankfurt am Main: Suhrkamp.

Marquard, O 1989. Kant und die Wende zur Ästhetik, in Aesthetica und Anaesthetica. Zürich: Ferdinand Schöningh.

Martin, G 1965. Allgemeine Metaphysik. Berlin: Walter de Gruyter.

Van Wyk, G M J 1989. Etiek en dialoog - die formalismeprobleem in die diskoersetiek van Jürgen Habermas. M A-verhandeling, Universiteit van Port Elizabeth.

Welsch, W 1988. Unsere postmoderne Moderne. Weinheim: VCH Verlagsgesellschaft. 